\title{
Redigir a intimidade: escrita mediada e relações sociais na América portuguesa
}

\section{Writing the intimity: mediated writing and social relations in Portuguese America}

\author{
Sílvia Rachi*
}

\begin{abstract}
Resumo
Este artigo é um recorte de pesquisa mais abrangente, desenvolvida na Universidade Federal de Minas Gerais, por meio da qual investigamos os usos sociais da escrita feito por mulheres, na Capitania de Minas Gerais, no período de 1780-1822. O corpus documental selecionado apresenta como principais fontes 557 testamentos post mortem pertencentes ao acervo do Arquivo do Museu do Ouro/Instituto Brasileiro de Museus (IBRAM)/Casa Borba Gato, em Sabará/MG, referentes ao território da então Comarca do Rio das Velhas. Foram levantados todos os documentos de mulheres registrados no referido intervalo de tempo. Partimos do pressuposto de que esses sujeitos, nas sociedades do Antigo Regime, mesmo impossibilitados do acesso ao aprendizado das primeiras letras, usaram a escrita, via oralidade, redigindo por outras mãos. Para efeito de nossa análise, pautamo-nos em autores referenciais no estudo de nossa sociedade colonial, além de estabelecermos diálogo com a linguística.
\end{abstract}

Palavras-chaves: Escrita. Oralidade. Sociedade colonial. Testamentos. Antigo Regime.

\begin{abstract}
This article is part of a larger research done at Universidade Federal de Minas Gerais, in which we investigated the social uses of writing by women in the Minas Gerais "Capitania" from 1780 to 1822. The documental corpus documental used presents, as main sources, 557 post mortem wills kept at Arquivo do Museu do Ouro/Instituto Brasileiro de Museus (IBRAM)/Casa Borba Gato, in Sabará/MG, relating to the territory of Rio das Velhas. All the documents pertaining to womem on the time period were analyzed. We
\end{abstract}

\footnotetext{
* Doutora em História da Educação pela Faculdade de Educação da Universidade Federal de Minas Gerais. É professora do Departamento de História e da Pós-graduação na Pontifícia Universidade Católica de Minas Gerais. E-mail: silrachi@yahoo.com.br
} 
started out considering such subjects as utilizing writing, even though they were denied the teachings of "first letters". Such use was through orality, written by other hands. For the purposes of this work, we both considered referential of colonial society as well as a dialogue with linguistics studies.

Keywords: Writing. Orality. Colonial society. Wills. Ancien Regime.

Escrever é revelar. É dar a conhecer representações sobre si e os outros. Forma de se colocar no mundo, de expressar ideias, recorrendo aos fragmentos do passado e às projeções do amanhã. Por caminhos convencionais ou inusitados, homens e mulheres, em diferentes épocas, deixaram no papel suas versões da própria existência, desvelando, em linhas escritas, aquilo que gostariam de eternizar.

Indagamo-nos, contudo: como redigia, nas sociedades do Antigo Regime, quem não detinha a habilidade de escrever? Por quais meios deixavam registradas demandas, expectativas e lembranças? Acreditamos que escreviam por outras mãos, ou seja, ditando. No referido contexto, em que o domínio da técnica da escrita era capital de poucos, principalmente do segmento masculino, branco e abastado, redigir tornou-se tarefa diversa, processando-se, mormente, por intermédio de um mediador. Pautados nas orientações de Mikhail Bakhtin, ${ }^{1}$ entendemos que o autor do texto seria aquele que fornece os conteúdos redacionais a partir do conhecimento e da avaliação que faz do contexto extraverbal.

Ao partimos dessa premissa, intencionamos evidenciar, neste trabalho, a escrita feminina das relações sociais na América portuguesa. Mais especificamente no que tange aos vínculos existentes entre proprietárias e crias da casa na sociedade mineira colonial, no período de 1780 a $1822 .{ }^{2} \mathrm{~A}$ escolha do público feminino justifica-se uma vez que a ele não era oferecido,

\footnotetext{
${ }^{1}$ BAKHTIN, Mikhail (Volochinov, V.N). Marxismo e filosofia da linguagem, São Paulo, Hucitec, 1981.

${ }^{2}$ Este artigo é recorte de pesquisa abrangente, desenvolvida na Universidade Federal de Minas Gerais, que contou com o apoio financeiro da Coordenação de Aperfeiçoamento de Pessoal de Nível Superior (CAPES). 0 corpus documental selecionado apresenta como principais fontes 557 testamentos post mortem, das duas últimas décadas do século XVIII até 1822, pertencentes ao acervo do Arquivo do Museu do Ouro/ Instituto Brasileiro de Museus (IBRAM)/Casa Borba Gato, em Sabará/MG, referentes ao território da então Comarca do Rio das Velhas. Foram levantados todos os documentos de mulheres registrados nesse período. As referências à documentação do acervo dessa instituição serão feitas no texto iniciando-se pela sigla MO/CBG/CPO/LT (Museu do Ouro/Casa Borba Gato/Cartório do 1ํㅇ́ćlio/Livro de Testamento), seguida dos números específicos dos livros - cotas atuais e cotas antigas (número entre parênteses) - e das folhas consultadas.
} 
de maneira sistematizada, o ensino das primeiras letras, configurando-se como segmento social majoritariamente iletrado. ${ }^{3}$

Empenhamo-nos em tentar captar a complexidade que permeia as relações entre escrita e oralidade. Consideramos imprescindível, portanto, a definição das circunstâncias em que se deu o discurso consubstanciado em texto, e, também, a compreensão dos movimentos caracterizadores dos atos de escrita. Significa dizer que buscamos entender como os protagonistas de uma dada situação de comunicação transportam para o ditado/escrita seus saberes, memórias e intenções. Objetivamos, assim, decodificar as mensagens elaboradas, entendendo-as como "encontro dialético" entre os partícipes da ação de escrever. Para efeito de nossa análise, utilizamos a documentação cartorária, em particular, os testamentos, por serem redações oriundas de uma narrativa oral.

Narrando sobre os supostos ou reais envolvimentos afetivos e as relações de poder, as testadoras "conceberam" textos diferenciados, nos quais as marcas de autoria traduziram subjetividades mescladas aos traços do cenário social. Alicerçadas nas experiências sociais, ao "escreverem" por intermediários colocaram, na folha em branco, memórias e desejos, registrando, desse modo, aspectos de suas vivências.

\section{Pelos bons serviços que me fizeram e amor que lhes tenho: a escrita dos vínculos entre proprietárias e crias da casa}

A fluência em lidar e ditar temáticas do cotidiano, referindo-se à cria, pode ser identificada no testamento de dona Teresa Andrada Soto Maior, elaborado em 19 de outubro de 1793. Viúva e proprietária de "casas de telhas no arraial" e de outros pertences, a testadora, além de ter dívidas a honrar, "assinou" o documento em cruz e declarou não saber ler nem escrever. Entretanto, demonstrou desenvoltura ao ditar suas disposições e ao utilizar

\footnotetext{
${ }^{3} \mathrm{O}$ sentido do termo iletrado, neste trabalho, não é exatamente o de expressão contrária à acepção de letrado no século XVIII. De acordo com o Vocabulario Portuguez \& Latino [...], do padre Raphael Bluteau, letrado significa "homem ciente; versado nas letras; homo litteratus" (BLUTEAU, Raphael, Vocabulario portuguez \& latino: aulico, anatomico, architectonico... Coimbra: Collegio das Artes da Companhia de Jesus, 1712-1728, v. 5,8 v. p. 90). Aqui, nomeamos iletrado a quem não escrevia/grafava nenhuma palavra ou registrava apenas o nome e/ou sinais equivalentes, isto é, quem não redigia com as próprias mãos. Isso não significa equipará-los a analfabetos ou a não detentores de algum grau de letramento, como se compreende este conceito na atualidade. Pelo contrário, acreditamos que, por viverem em sociedade perpassada pela escrita, esses sujeitos, provavelmente, estabeleceram relações com a mesma, fator propiciador do desenvolvimento de níveis de letramento. Há de se considerar, ainda, o fato dos aprendizados da leitura e da escrita acontecerem em momentos dissociados no contexto abordado (aprendia-se a ler antes de escrever). Por consequência, muitos daqueles desprovidos da técnica de escrever, poderiam ser leitores.
} 
a redação do testamento de maneira dinâmica, referindo-se aos bens e aos sentimentos que dizia cultivar por determinada ex-escrava, Faustina, cria em sua casa. Com essa intenção, declarou:

Possuo escravos e umas lavras na vizinhança do Arraial de São Gonçalo do Caeté aonde tem minha situação, o qual consta de títulos que tenho: as dou pelo amor de Deus à crioula Faustina, que foi minha escrava, cria e é hoje forra, e aos mais escravos que coartei para que morem na dita situação, trabalhem nas ditas lavras, unidos em boa paz como suas que ficam. ${ }^{4}$

A descrição do sentimento pela ex-escrava apresenta elementos da religiosidade, vozes sociais informantes da enunciação, como a afirmativa "pelo amor de Deus," que denota a devoção religiosa e a virtude da compaixão pela "crioula Faustina". Além dessa característica, recorrente nos testamentos, a narrativa da testadora demonstra organicidade e lógica. Inicialmente, dona Teresa descreve a situação desta ex-escrava, justificando sua "doação", pois em ordem de importância do lugar ocupado pelos ex-escravos, relata o fato de Faustina ter sido não apenas escrava, mas cria, sendo, naquela altura, forra. Somente depois, como se desejasse diminuir a importância dos outros escravos, dispõe acerca do que também virá a lhes pertencer, ou seja, as "lavras na vizinhança do Arraial de São Gonçalo aonde tem minha situação”.

A rememoração da condição de cria da ex-escrava Faustina acaba por formatar o texto de maneira particular, com base no sentimento e no lugar social (de ex-proprietária) ocupado pela testadora no momento em que dita. A lembrança da testadora não se deu de maneira "completa", de forma a remontar o passado tal qual ele era. Memórias não são espelhos da realidade, mas reconstruções elaboradas a partir dela. As recordações são sempre fragmentadas, compõem-se de estilhaços do vivido, das seleções e escolhas feitas por quem narra, pelos sujeitos autores das lembranças. Esses "sujeitos-autores" lançam o olhar para o passado, mas alicerçados em novas bases, em experiências presentes, particulares.

Daí decorre o entendimento de que as lembranças apresentam caráter subjetivo, mesmo compartilhadas coletivamente e reconstruídas a partir, inclusive, de elementos pertencentes a uma memória coletiva. Os discursos sociais estão a todo tempo presentes e, como nos explica Bakhtin, mesclam-se à experiência do sujeito que, ao enunciar, encontra-se numa relação dialética. Por isso, as escrituras são diferenciadas, isto é, os registros da memória ou as "composições" textuais deles emanadas apresentam aspectos

$\overline{{ }^{4} \mathrm{MO} / \mathrm{CBG} / \mathrm{CPO} / \mathrm{LT} 37(55)}$, fl. 167, destaque nosso. 
individualizantes e individualizados, ainda que formatados por certos padrões discursivos.

A menção às crias da casa e aos enjeitados surge em recorrência na escrita cartorária. É o que verificamos, também, na narrativa de Maria de Sousa Nascimento. Essa testadora nascera na Vila de Sabará, era viúva de Domingos Rodrigues e mãe de dez filhos. $O$ testamento, assinado em cruz, fora elaborado na fazenda Boa Vista, em 6 de outubro de 1776, quando ordenou que seu corpo morto fosse envolto no hábito da Arquiconfraria de São Francisco, "[...] onde tinha vontade de entrar por irmã e professar, pagando esmola que for justa e pretendo fazer [...]". ${ }^{5}$

Ao ditar as disposições, advertiu: "[...] quando por algum incidente eu não consiga entrar na dita irmandade então serei sepultada na minha matriz em hábito de São Francisco, bem entendido que é na Igreja de Santo Antônio da Roça Grande". Notemos que a testadora utiliza-se da redação do testamento para explicar minuciosamente onde desejava ser enterrada. Para evitar quaisquer enganos, argumenta no sentido de deixar "bem entendido" que o lugar correto para o sepultamento era a Igreja de Santo Antônio da Roça Grande, denotando a consciência de que a entrada na Irmandade de São Francisco poderia não se concretizar. Precisou, então, empregar recursos verbais para explicar como deveria ser realizado o sepultamento. Certamente o redator escreveu de maneira a reforçar essa determinação, mas, muito provavelmente, o fez pelo fato de a narradora do texto ter enfatizado tal aspecto. No desenrolar do ditado afirmou possuir:

[...] [Um] sítio e seus pertences, de alguns [matos], ainda que muito poucos, casas de vivenda coberta de telhas, senzala e paiol coberto de capim e engenho de mandioca já danificado e uma capoeira junto ao Rio das Velhas [...] mais escravos seguintes: Gonçalo, crioulo; Francisco, crioulo; Jorge, crioulo; Domingos Benguela; Antônio Mina; Joaquim Benguela; João da mesma nação; Rita crioula; Sebastiana crioula; Caetana crioula; Vitoriana crioula; Francisca parda; Joaquina parda, filha da dita; Francisco e João pardos, filhos da mesma; Rosa aleijada, filha da dita crioula Sebastiana. ${ }^{6}$

A testadora consegue precisar os nomes dos escravos, de onde provinham e de quem eram filhos. Constrói, desse modo, narrativa detalhada, mencionando, por exemplo, o fato da filha da crioula Sebastiana ser aleijada. Demonstra ter conhecimento do plantel que possuía, talvez, por administrar a propriedade, posto ser viúva. Ainda que tivesse dez filhos, os quais poderiam

\footnotetext{
${ }^{5} \mathrm{MO} / \mathrm{CBG} / \mathrm{CPO} / \mathrm{LT} 39(58)$, fls. 91-95.

${ }^{6} \mathrm{MO} / \mathrm{CBG} / \mathrm{CPO} / \mathrm{LT} 39(58)$, fls. 91-95.
} 
se dedicar aos negócios familiares, Maria de Sousa narra pormenores acerca das posses e finanças da família e como estas deveriam ser encaminhadas. Mesmo sem saber escrever, pois marca o testamento com uma cruz, Maria do Nascimento deixa transparecer na narrativa o domínio da administração da casa, construindo texto preciso e coeso. Ao nomear cada escravo e não apenas quantificá-los, reforça a propriedade dos bens e utiliza-se da escrita de modo a reafirmar o senhorio sobre os mesmos. Dando sequência às disposições, afirma:

[...] a meu filho Guilherme dei por conta de sua legítima paterna uma crioula por nome Teresa e a meu filho Joaquim um pardo por nome Manuel, sendo este ainda de menor idade, também por conta de sua legítima paterna, e a minha filha, senhorinha Maria, se juntou oito mil e quatrocentos; e a meu filho Sebastião quarenta e duas oitavas. Declaro que uma mulata, por nome Joana, deixou o falecido meu marido tomando [?] na sua terça para me servir e as suas filhas, Maria e Ana, até estas se casarem e que casadas ele lhe passe assim sua carta de liberdade, e por isso as ditas minhas filhas, visto se não terem ainda até o presente casado, farão a dita mulata Joana o benefício que muito quiserem e lhes parecer [...]. . $^{7}$

Com as determinações, a testadora define o destino dos cativos e deixa entrever na narrativa as negociações e decisões realizadas, tomando-se os escravos efetivamente como bens a serem legados. Explica com clareza as disposições do falecido marido, regressando aos legados que ele lhe conferira. $\mathrm{O}$ texto produzido cumpre, nesse trecho, a finalidade de recuperar acontecimentos e resoluções. Nesse sentido, esclarece como tinha procedido em relação às legítimas dos filhos, expondo, assim, um pouco da história familiar.

No ditado, Maria de Sousa atribui às filhas autonomia para que procedam da maneira que julgarem melhor com relação ao destino da cativa Joana. Este último aspecto é denotativo do poder da escrita do testamento, pois essa disposição acaba por desfazer determinações do falecido marido. Declara também que,

[...] por reconhecer que uma parda minha escrava por nome Maria Vitória, filha da dita parda Joana, é minha sobrinha, por ser filha de meu irmão João da Costa, é minha vontade que fique liberta, para o que a tome na minha terça, com a obrigação do dito seu pai mandar dizer oitenta missas de esmolas de meia oitava por minha alma ou ainda a dita parda e com apresentação da certidão [...] peço e rogo muito de [fazer] a meus filhos e herdeiros que se haver quem queira libertar e a alguns dos pardos ou pardos que forem crias

$\overline{{ }^{7} \mathrm{MO} / \mathrm{CBG} / \mathrm{CPO} / \mathrm{LT} 39(58)}$, fls. 91-95. 
de minha casa, dando o seu justo valor, que lhes convenham em lhes fazer esta equidade [...] pelo amor [?] que lhes tenho, os desejos ver a todos bem amparados. $^{8}$

Aqui, torna-se importante destacar que o reconhecimento do parentesco com a parda Maria Vitória concede singularidade ao texto. Maria não reafirma disposições do marido, mesmo em parte modificadas, mas revela que tomou decisões a partir de determinado conhecimento. É possível que o nascimento da cativa ou a revelação de tal parentesco tenha se dado apenas após a morte de Domingos Rodrigues. De qualquer modo, a percepção da realidade acabou por orientar e instituir a redação de seu texto. Redação, aliás, que, para ser construída, extrapolou o mero relato de informações adquiridas pela testadora e demandou a capacidade de avaliar, a partir da posse dessa informação, a melhor atitude a ser tomada, para mais tarde ser firmada no papel.

Em relação às crias da casa, a testadora pede e roga aos herdeiros que, desejando libertá-las, assim o façam, dado o amor que lhes declarava sentir. Numa primeira leitura, temos a impressão que Maria de Sousa atribui autonomia aos herdeiros para agirem como melhor julgassem. No entanto, na sequência da frase, alerta sobre o amor declarado pelas crias, como se buscasse com seu argumento convencer do quanto apreciaria caso "alguém" proporcionasse a elas a liberdade. Benevolência que a testadora gostaria apenas de demonstrar com sua narrativa? Talvez. Se sua intenção era conferir a liberdade às crias, por que não o fez? Contudo, se, por um lado, Maria não as liberta, por outro, da maneira como constrói a narrativa, deixou as portas abertas para que isso ocorresse. Ao mencionar a libertação das crias por quantia justa, coloca a manumissão enquanto uma equidade, podendo ser realizada por outros, com a autorização dos herdeiros. Maria de Sousa atribuiu, assim, valoração à liberdade, considerando-a como respeito à igualdade de direitos que crias e outros cativos teriam. Por fim, a testadora dispõe sobre as dívidas e créditos, ou seja, matéria costumeira dos testamentos:

\footnotetext{
Declaro que as dívidas que devo constam de créditos e obrigações; porém sem embargo disso, se aparecer alguma pessoa bem conceituada que diga que lhe devo alguma coisa, sendo até a quantia de dez oitavas meus testamenteiros, sem mais contenda e justiça e só com juramento da dita pessoa lhe satisfará; e ao meu testamenteiro deixo uma carta fechada para, debaixo de segredo natural, me cumprir o determinado nela, sem ser obrigado a declarar o seu contexto e só assim o jurar que cumpriu o que lhe determinei. ${ }^{9}$
}

\footnotetext{
${ }^{8} \mathrm{MO} / \mathrm{CBG} / \mathrm{CPO} / \mathrm{LT} 39(58)$, fls. 91-95.

${ }^{9} \mathrm{MO} / \mathrm{CBG} / \mathrm{CPO} / \mathrm{LT} 39(58)$, fls. 91-95.
} 
Nesse trecho, o papel assumido pela oralidade na sociedade colonial aparece em destaque. Por um lado, com sua narrativa, a narradora, além de registrar dívidas - as quais, muitas vezes, se firmavam apenas pelo empenho da palavra -, ressalta o valor que a palavra de pessoa "bem conceituada" poderia ter, independentemente da existência de anotações ou apontamentos. Por outro, ao estipular o limite do valor a que chegaria alguma dívida da qual porventura não se lembrasse, demonstra ter conhecimento do máximo contraído em empréstimo, utilizando-se da escrita de maneira a confirmar esse entendimento e se preservar de futuras cobranças não correspondentes à realidade, mesmo que alguém alegasse o contrário. Em igual medida, na elaboração do texto, revela-nos certo convívio com escriturações, ao afirmar que deixava ao testamenteiro "uma carta fechada" para cumprir, "debaixo de segredo natural”, as disposições.

A alusão às crias nesse testamento mostrou-se breve e serviu-nos apenas como guia para localizarmos o documento e, junto a ele, outras informações bastante ricas sobre os sentidos e finalidades da escrita. Esse fio condutor da narrativa abriu-nos janelas para conhecer o registro de memórias familiares, a autonomia concedida aos herdeiros, as alforrias e o agenciamento dos negócios. Fatores que se configuravam como motivações para a escrita. Todavia, cabe destacar que, se as palavras sobre as crias foram, nesse caso, econômicas, a alusão aos sentimentos que as mulheres diziam ter por esses indivíduos mostrou-se recorrente nos textos testamentais.

As crias foram mencionadas por diferentes testadoras, mas também diferentes foram as maneiras como "escreveram" sobre elas. Francisca Gomes Pereira, natural de Santa Luzia, filha legítima de Francisco Gomes e de Antônia Pereira Baião, ao ditar seu testamento, em janeiro de 1803, dizendo não saber ler nem escrever, estabelece:

Declaro que sou senhora e possuidora de um moleque digo de um mulatinho por nome José e de um crioulo por nome Manuel, ambos filhos de duas escravas minhas, os quais ambos por serem minhas crias e pelo amor que lhes tenho os deixo forros e libertos e sendo necessário meu testamenteiro lhes passará a cada um sua carta de liberdade..$^{10}$

A escrita, uma vez mais, "serviu" para a legitimação das alforrias das crias e para a demonstração dos afetos que as testadoras diziam possuir por elas. Não estamos, é claro, afirmando que as alforrias, em suas diferentes modalidades, são frutos tão somente das concessões generosas e amorosas

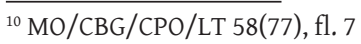


de seus senhores para com os escravos. Como nos mostra a historiografia, os cativos e forros foram protagonistas de suas histórias e construíram estratégias de resistência e de negociação relativas às vivências e atuações no cenário social. ${ }^{11}$ Porém, a recorrência nos textos analisados de dizeres que pretendem revelar as supostas relações estabelecidas entre senhores e escravos, principalmente entre proprietárias e cativos ou ex-cativos, instiganos a problematizar acerca da necessidade e das formas como se efetuaram os registros dessas convivências.

Francisca Gomes, enquanto possuidora do "mulatinho" José e de "um crioulo por nome Manuel", desejou explicar a origem de ambos e o motivo do amor que lhes dizia ter. Justificou as alforrias "escrevendo" acerca da convivência mantida com José e Manuel, deixando perenizado o que afirmava sentir e porque sentia. Seu texto, nesse aspecto, apresenta-se mais detalhado do que o do exemplo anterior, ou seja, o testamento de dona Teresa Andrada Soto Maior.

Embora as duas testadoras "falem" e "registrem" a respeito dos motivos das "concessões" às crias, a primeira se justifica com base em explicações de natureza religiosa, remetendo, como dito, sua decisão ao sentimento de compaixão, ao expressar que "umas lavras, na vizinhança do Arraial de São Gonçalo do Caeté, aonde tem minha situação, o qual consta de títulos que tenho: as dou, pelo amor de Deus, à crioula Faustina, que foi minha escrava, cria e é hoje forra". Já Francisca Gomes narra sobre seu sentimento, fundamentando o "amor" cultivado por suas "crias" e explicando o porquê da alforria de José e Manuel.

As experiências pessoais se misturam aos elementos do contexto social e histórico. Se, por um lado, as alforrias eram práticas comuns e até mesmo corriqueiras no ato de testar, suas motivações e propulsões diferenciavamse, assim como distintas eram as formas de escrevê-las e dá-las a conhecer. Desenvolvemos, aqui, reflexões - ancorados nas elaborações de Justino Pereira de Magalhães ${ }^{12}$-, as quais nos permitem afirmar que a fixidez inerente à escrita pode forjar ou alterar a memória, sendo a situação da enunciação um contexto de luta, quando se processa a retenção do conteúdo a ser dito e mostrado, ou seja, a representação que se possui do real.

\footnotetext{
${ }^{11}$ A este respeito ver, particularmente para a região estudada, PAIVA, Eduardo França. Escravos e libertos nas Minas Gerais do século XVIII: estratégias de resistência através dos testamentos. 2. ed. São Paulo: Annablume, 1995; RAMOS, Donald. Do Minho a Minas. Revista do Arquivo Público Mineiro, Belo Horizonte, n. 44, p. 132-153, jan.-jun. 2008; GUIMARÃES, Carlos Magno. A negação da ordem escravista: quilombos em Minas Gerais no século XVIII. São Paulo: Ícone, 1988.

${ }^{12}$ MAGALHÃES, Justino Pereira de. Ler e escrever no mundo rural do Antigo Regime: um contributo para a história da alfabetização e da escolarização em Portugal. Braga: Universidade do Minho, 1994.
} 
A esse respeito, isto é, aos embates em torno do que é apropriado e divulgado, também Roger Chartier, referindo-se às pluralidades das práticas de leitura, esclarece-nos:

Os processos de imitação ou vulgarização são mais complexos e mais dinâmicos e devem ser pensados, antes de tudo, como lutas de concorrência em que toda a divulgação, outorgada ou conquistada, produz ao mesmo tempo, a procura de uma nova distinção. ${ }^{13}$

Daí se depreende que, assim como ocorre em relação às práticas de leitura, as formas plurais de escrita e as seleções que lhes são inerentes conferirão sentido aos conteúdos. Os nexos e os direcionamentos dos textos e, do mesmo modo, as elaborações discursivas que lhes originam são frutos de apropriações e apreensões diversificadas do real. Os elementos do contexto extraverbal, captados pelos agentes históricos, de múltiplas maneiras, corroboram para a autoria dos textos ditados.

É o que podemos constatar, por exemplo, no testamento de Vitória Gonçalves Geraldes, que na fazenda de São Sebastião, localizada em Nossa Senhora da Conceição do Rio das Pedras, por "atenção" ao fato de haver criado Antônia e em reconhecimento aos bons serviços por ela prestados, alforriou sua escrava. Essa proprietária ditou o testamento em 1795 e rogou para que o assinassem. Era solteira, sem filhos e possuía especial devoção por São José e Santo Antônio. Leiamos trecho de seu testamento:

Declaro que na dita sociedade há uma crioula por nome Antônia e em atenção a havê-la criado e aos bons serviços que me tem feito a deixo forra pela parte que me pertence e pela metade do que me pertence digo que pertence ao meu sócio quando ele não queira contribuir para este benefício, minha testamenteira lhe passará este valor [respeito] a sua parte lhe passará carta de liberdade $\left[\ldots . . .^{14}\right.$

Vitória explicita a situação de sua escrava Antônia, que, segundo a narradora, encontrava-se na "dita sociedade", levando-nos a supor que a mesma vivesse em sua companhia. O fato de afirmar ter "criado" a escrava difere dos casos mencionados, os quais dizem respeito às crias. Criar implicava cuidados diretos, um conjunto de atitudes voltadas a garantir a sobrevivência e bem-estar, diferentemente das crias que nasciam nas casas dos proprietários, convivendo com os mesmos, mas cuja criação, normalmente,

${ }^{13}$ CHARTIER, Roger, Leituras e leitores na França do Antigo Regime. Tradução Álvaro Lorencini. São Paulo: Ed. Unesp, 2004, p. 17.

${ }^{14} \mathrm{MO} / \mathrm{CBG} / \mathrm{CPO} / \mathrm{LT}$ 50(60), fls. 104-109. 
cabia à mãe escrava. Todavia, numa ou noutra situação, a criança havia nascido ou pelo menos crescido na casa de seu proprietário.

Na narrativa de Vitória, há uma sequência lógica da apresentação dos acontecimentos. Em primeiro lugar, a testadora diz onde Antônia está, explica que é sua proprietária e que a criou e determina a alforria, pagando, inclusive, pela parte de seu "sócio" de forma a garantir a liberdade a Antônia. Para tanto, demonstrando conhecimento da realidade, orientou a testamenteira a passar o valor relativo ao preço da liberdade de Antônia a seu sócio, caso ele, de alguma maneira, se opusesse a alforriá-la. Ordenou ainda que, ao final do processo, a testamenteira passasse a carta de liberdade à escrava.

Mesmo que o redator do texto, ou outra pessoa presente no ato, tenha dado, durante o ditado do testamento, organicidade ao conteúdo, é inegável que elementos específicos, como o que a testamenteira deveria fazer para garantir a liberdade de Antônia e a explicação acerca da identidade dessa escrava, apresentam coerência, atribuindo racionalidade à narrativa. Nesse sentido, a autora-oral trabalha com os fatos: a existência e criação de Antônia; com hipóteses: com o que poderia dar errado no processo de alforria; e com resoluções: como garantir o cumprimento de sua determinação. Esse conjunto de elementos discursivos, quais sejam, fatos, hipóteses e resoluções, encadeia os acontecimentos, estabelecendo os nexos entre eles. Além da mera disposição sobre o destino da escrava, neste caso a escrita assumiu a função de descritora das situações vividas, servindo para justificar as ações e para precaver possíveis desvios às determinações.

Esse panorama ou caminho do escrito é característico do contexto em estudo, ou seja, da sociedade escravista, pois nela os fatos mencionados ocorreram como descritos. Dito de outra maneira: no contexto escravista (colonial e/ou imperial) as alforrias condicionais e as coartações dos filhos das escravas, que viveram na casa de seus senhores, fizeram parte da realidade histórica. Cabe frisar, portanto, que as características do contexto extraverbal são constituintes da forma, do estilo e do conteúdo. Em última instância, dos usos conferidos à escrita, mesmo por aqueles que não sabiam escrever.

Neste ponto, evocamos as formulações de Maurizio Gnerre ${ }^{15}$ referentes às relações dos diversos grupos sociais com a escrita. Há aqueles com o domínio da escrita (enquanto apropriação dos códigos) e os que não o possuem (enquanto habilidade autônoma). Aqui, ressaltamos os usos sociais da escrita por um grupo que tradicionalmente não possuía as capacidades

${ }^{15}$ GNERRE, Maurizio. Linguagem, escrita e poder. 5. ed. São Paulo: WMF Martins Fontes, 2009. 
de ler e escrever. Significa dizer que, mesmo sem tais habilidades, essas mulheres reafirmaram uma memória e expuseram narrativas que desejaram dar a conhecer. A redação do testamento funcionou como acontecimento, ocasião na qual o passado, os valores e as expectativas firmaram-se em suporte específico.

Sem saber ler nem escrever e marcando seu testamento com uma cruz, em janeiro de 1794, na Freguesia de Nossa Senhora da Conceição do Rio das Pedras, também Juliana Sanches da Silva registrou a respeito de suas crias Helena, Narcisa, Cecília, Perpétua, Bernardo, Maria e Vicência, filhos da escrava Maria, de "nação mina", já falecida. A testadora era natural da Costa da Mina e fora batizada em São João de Ouro Fino, na Freguesia de Nossa Senhora da Conceição de Antônio Dias, Comarca de Vila Rica, cujo sacramento recebeu adulta. Sobre as referidas crias determinou:

[...] os quais pelos bons serviços que me fizeram e amor que lhes tenho, lhes tenho passado a carta de liberdade a cinco de junho de 1792 anos com as cláusulas nelas declaradas e que neste meu testamento novamente as expresso a saber: Narcisa com a condição que daria para o meu enterro e sufrágios a quantia de quatorze oitavas, a Cecília com a obrigação de dar dezoito oitavas cuja quantia já recebi e lhe entreguei a sua carta e na qual também libertei as suas duas filhas digo libertei as suas filhas Agostinha, Angélica e Luísa; Perpétua com a condição de dar para o meu enterro e sufrágio a quantia de quatorze oitavas, Helena com a condição de dar para o meu enterro e sufrágios a quantia de quatorze oitavas e na carta que lhe passe de sua liberdade lhes forrei os seus filhos Antônio pardo, Luciano e Hilária crioulos; Bernardo com condição de dar para o meu enterro e sufrágios vinte oitavas de ouro cujas cartas as conserva em seu poder o senhor alferes Eusébio Francisco Lopes e lhes serão entregues depois de cada um satisfazer a parte que lhes toca. ${ }^{16}$

O modo de Juliana elaborar e partilhar pensamentos e decisões sobre as crias é extremamente representativo da autonomia em escolher e compor a matéria a ser firmada no papel. Na verdade, sua narrativa trata-se da socialização de hábitos, crenças, impressões, sentimentos e necessidades. Assume função descritivo-explicativa, referindo-se a relatos do passado e a determinações futuras. Os apontamentos deixam entrever aspectos da convivência com os cativos, expondo os acontecimentos cronologicamente, quando, por exemplo, registra o momento da entrega da carta de liberdade aos escravos. Ademais, ainda que tenha sido estimulada e orientada a registrar tal momento, a testadora faz questão de expressar novamente as cláusulas contidas nas cartas. Costume da época, a reafirmação em testamento das liber-

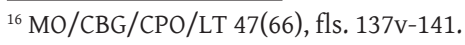


dades concedidas aos escravos revela o uso da escrita de forma a ratificar, inclusivamente, decisões já legalizadas, prática, ao que parece, conhecida por nossas testadoras. Nesse sentido, explica-nos Jack Goody, que os textos postos no papel são retomáveis e verificáveis, passíveis de um "esquadrinhamento retrospectivo", ${ }^{17}$ permitindo-se a eliminação das incoerências, as ratificações. Ressaltemos que, neste caso, o esquadrinhamento retrospectivo do conteúdo escrito deu origem a novo texto, o qual nasceu de uma enunciação oral. Revista e examinada, essa escrita compõe o quadro coerente, descortinando valores, crenças e hábitos.

Novamente, a alforria condicional ganhou a cena e surgiu atrelada aos discursos sociais, especialmente às crenças e aos hábitos religiosos. Isto é, a escrita emerge relacionada ao espaço externo de comunicação. Minuciosamente, Juliana expôs as exigências para a efetivação das liberdades das crias, evidenciando uso circunstanciado da escrita. Outro aspecto relevante do testamento refere-se à ordem assumida pelas disposições. Em contraposição ao "modelo" testamentário, a testadora inicia seu texto com as determinações acerca das coartações e apenas depois declara os bens. Na sequência de seu testamento, explicita:

Declaro que os bens que possuo são uma morada de casas em que moro e alguns móveis de pouco valor cujas casas e móveis os deixo às minhas crioulas e crioulo acima mencionados, para nelas morarem, e os móveis a Narcisa e Cecília [que] os repartirão entre todos igualmente. Declaro que as crioulas Vicência e Maria já eram libertas porque assim as mandei batizar por forras. Declaro que para os sobreditos pagarem as referidas quantias lhes dará meu testamenteiro um ano, e tendo o recibo de cada um o que lhe toca, lhes entregará a sua carta e o mesmo tempo lhe concedo para mostrar em juízo satisfeitas as minhas disposições; e pago o meu funeral. ${ }^{18}$

A escrita de Juliana nos parece revelar, assim, certa hierarquia e lógica conferidas às disposições em detrimento ao modelo rígido do testamento. Em primeiro lugar, evidenciou quem eram as crias e, logo em seguida, dispôs dos bens para favorecimento das mesmas. Imputando racionalidade ao discurso, inverteu o modelo ou padrão do texto testamentário, qual seja: encomendação do corpo, disposição dos bens e depois as alforrias, para principiar a narrativa com a declaração das liberdades.

Tendo em vista que deixaria seus legados para Helena, Narcisa, Cecília, Perpétua, Bernardo, Maria e Vicência, é como se fizesse questão de

\footnotetext{
${ }^{17}$ GOODY, Jack e WATT, Ian, As consequências do letramento. Tradução Waldemar Ferreira Neto. São Paulo: Paulistana, 2006, p. 49-50.

${ }^{18} \mathrm{MO} / \mathrm{CBG} / \mathrm{CPO} / \mathrm{LT}$ 47(66), fls. 137v-141.
} 
apresentá-los no início do ditado, explicando as condições das manumissões, para mais tarde dizer sobre a herança. Ao "escrever", subvertendo a ordem do escrito, Juliana deixa-nos perceber, no texto, aspectos da narrativa emanada da oralidade, pois a redação não se encontra imobilizada pela ordem clássica do testamento. Ao contrário, mostra-se flexível e diferenciada. Mesmo existindo protocolos específicos delineadores do conteúdo do documento, a testadora "redigiu" desejos e determinações, utilizando-se da escrita de maneira autônoma, liberta e pessoal.

Traços subjetivos, correlacionados ao contexto extraverbal, podem ser verificados, do mesmo modo, no discurso de Ana Duarte da Silva, natural da Costa da Mina, casada com Teotônio Ramos Pereira, de cujo matrimônio não teve filhos. Ao fazer o testamento, em 7 de fevereiro de 1792, declarou não saber ler nem escrever, marcando-o com uma cruz. Determinou que seu corpo fosse amortalhado em lençol branco e sepultado na matriz de Nossa Senhora do Pilar de Congonhas do Sabará. Quando veio para as Minas, em "tenra idade", foi "batizada no Arraial de Raposos" e mais tarde passou a viver em Congonhas. Em ambos os lugares, Ana possuía casas de moradas. Vivendo nesta última localidade, criou Joaquina, "moça branca", enjeitada, para quem pretendia deixar seus pertences, entre eles brincos, uma vaca, um boi e dois tachos de cobre pequenos, sendo um "em bom uso e outro furado". ${ }^{19}$

Não parece de todo impróprio pensar que Ana usou a escrita de forma a ressaltar o fato da enjeitada Joaquina, criada por ela, ser "moça branca". Verbalizou esse "detalhe" em testamento, conferindo identidade social a Joaquina. Em uma sociedade escravista, esses "pequenos" dizeres assumiam dimensões mais amplas quando fixados no papel. Na sociedade em causa, a afirmação da cor branca traduzia o distanciamento da condição de cativo, tanto da própria pessoa quanto de seus ascendentes. Trata-se, na verdade, de um caminho para distinguir a "qualidade" do indivíduo. Nesse caso, a testadora não se ocupou em declarar seus sentimentos pela enjeitada, mas em destacar aspectos que a qualificassem como alguém que não era negra, cativa ou mesmo liberta.

Iniciativa expressiva da narradora diz respeito, igualmente, à afirmativa de que um de seus tachos encontrava-se "furado". Enquanto instrumento de trabalho e de uso doméstico, os tachos apresentavam grande importância para a sobrevivência das mulheres e de seus familiares. Esse utensílio

$\overline{{ }^{19} \mathrm{MO} / \mathrm{CBG} / \mathrm{CPO} / \mathrm{LT} 45(64)}$, fls. 13-16v. 
aparece em número significativo de testamentos. Dizer sobre eles na elaboração do texto era, em última análise, escrever sobre si. A existência de "tachos de cobre", tachos "de fazer doces", pequenos ou grandes, novos ou velhos, em "bom uso ou furados", foi constantemente registrada, deixando evidente, nas linhas redigidas, marcas e indícios do trabalho e da indústria dessas mulheres.

Neste sentido, a escrita foi utilizada como mecanismo de registro dos bens, mas, em especial, como meio de explicitar práticas sociais relacionadas ao mundo do trabalho, onde instrumentos e utensílios assumem valor concreto e simbólico. Os tachos de Ana, deixados para a enjeitada Joaquina, "continham", em sua descrição, o esforço, o trabalho e os sinais do desgaste, da labuta cotidiana. Deixá-los, descrevendo-os, significava muito mais que transferência de bens materiais. Tratava-se da transmissão daquilo que era significativo na vida da testadora. No registro minucioso desses objetos, a escrita assumiu a função de condensar as experiências, tornando-as conhecidas.

Objetos com significado importante deixados às crias, enjeitados e/ ou escravos estão presentes, de igual modo, na redação do testamento de dona Eufrásia Maria Francisca Xavier. Filha legítima de Manuel Rodrigues e de Teresa Maria dos Prazeres, dona Eufrásia veio de Lisboa para as Minas e ordenou, em testamento redigido no ano de 1792, que, quando falecesse, seu corpo fosse "envolto em hábito da Senhora do Monte do Carmo na Igreja da Ordem Terceira da mesma Senhora". Rogou para que assinassem por ela o documento, "por eu não poder fazer". Ordenou ao testamenteiro que, logo após seu falecimento, entregasse a Caetana Joaquina, sua cria, o oratório "com todas as imagens que se acharem dentro dele", bem como "a minha cama e [cômoda]". Em testamento assim declarou:

Possuo uma mesa, duas cadeiras, dois tamboretes torneados, um baú que está na sala, duas bacias de cobre de fazer doce, um candeeiro velho, e um [registro?] da imagem de São João Nepomuceno. Ordeno que se dê a Maria da Silva, minha escrava que foi, um tacho grande; e, a Úrsula se lhe dará o baú que está no meu quarto, uma bacia de arame de fazer doce e um registo de Nossa Senhora, uma cadeira, e um tamborete torneado, um candeeiro grande, e uma mesa pequena velha e um gancho de ferro. Declaro que tenho em meu poder uma mesa com duas gavetas que está na sala [?] empenhadas por oito ou doze vinténs, a qual mesa ficará em poder de Caetana até satisfazerem a dita quantia do empenho, então entregarão a meu testamenteiro. Também quero que se dê a Ângela, irmã de Úrsula, uma cadeira e um tamborete e um registo do santo Antônio. O mesmo se fará para com a crioula Ana dando-selhe uma mesa que está trocada por uma que emprestei a José Luís para a sua 
festa do Divino Espirito Santo, e um pilão também. Também quero [que] se dê a Gertrudes, minha cria, filha de Pontenciana, um registo de são Pedro e o manto que está sem renda, uma cadeira, quatro formas de fazer pão de ló. Declaro que todos os trastes que sobrarem desta minha petição, quero que se partam entre todos tantos forros como cativos em igual parte. Declaro que o negro Domingos, o deixo para servir a Caetana e [a] sua mãe. ${ }^{20}$

Na relação dos bens de dona Eufrásia, encontravam-se objetos de uso cotidiano: mesas, cadeiras e baús, além daqueles específicos para o preparo de alimentos: bacias e tachos de fazer doce e os objetos de valor simbólico/ religioso, a exemplo de imagens de santos de sua devoção. Para a cria Gertrudes, filha de Pontenciana, destinou um desses objetos de valor simbólico, o "registro de São Pedro", o "manto que está sem renda, além de uma cadeira" e as quatro formas que utilizava para fazer pão de ló.

Distintamente dos outros casos aqui mencionados, percebemos que no "texto" de dona Eufrásia, o lugar atribuído à sua cria Gertrudes não assumiu destaque ou foi ressaltado com relação aos demais escravos ou ex-escravos. Ao contrário. No início da narrativa, a testadora descreveu os bens e declarou o legado à ex-escrava Maria da Silva, como se lê: "ordeno que se dê a Maria da Silva, minha escrava que foi um tacho grande". Na sequência, deixou a Úrsula - que não explicita quem é - o baú, além de "uma bacia de arame de fazer doce e um registo de Nossa Senhora, uma cadeira, e um tamborete torneado, um candeeiro grande, e uma mesa pequena velha e um gancho de ferro". Ou seja, vários objetos e utensílios são legados a Úrsula, diferentemente dos deixados a Gertrudes.

As relações das senhoras com suas crias mostravam-se, portanto, nuançadas, sendo que em alguns casos a redação do texto intenciona revelar proximidade e afetuosidade. Em outros, apenas simples relato da existência desses sujeitos e de algumas medidas a eles relacionadas. Assim, a escrita do testamento, ao referir-se a indivíduos ocupantes de um mesmo lugar social, isto é, o de crias da casa, assume usos variados e funções distintas. Ora surge, preponderantemente, voltada para a descrição dos afetos, ora, de maneira objetiva, parece apenas cumprir meras formalidades. De uma maneira ou de outra, a testadora além de descrever os bens, explicitou as condições nas quais se encontravam, como quando mencionou "um candeeiro velho", "uma mesa pequena velha" ou "o manto que está sem renda". São dizeres que emanam de uma valoração e de certo detalhamento que dona Eufrásia julgou necessário proceder.

${ }^{20} \mathrm{MO} / \mathrm{CBG} / \mathrm{CPO} / \mathrm{LT}$ 45(64), fls. 108v-114v. 
Em testamento, muitas mulheres descreveram os bens de raiz, escravos e objetos e para quem os deixariam, explicitando em que condições se encontravam. Declararam a existência das "moradas de casas", "casas com quintal", fazendas ou sítios, normalmente para se referirem ao lugar onde viviam. Especificamente com relação aos objetos, em grande parte dos textos, esses vinham descritos tão somente como trastes "que possuo" e que se achavam no local de moradia, não se mostrando esses relatos como novidades. Chamou-nos a atenção, no entanto, a necessidade de algumas testadoras em detalhar as condições de certos pertences, particularmente daqueles relacionados ao mundo do trabalho. Desse modo, especificar os bens e descrevê-los, ao que nos parece, apresentava sentido de diferenciação, de maior importância concedida a tais elementos e, por decorrência, às atividades e experiências a eles relacionadas.

Pintura aquarelada da realidade, as escrituras testamentais revelam-nos diferentes modos como as testadoras viam e avaliavam suas experiências cotidianas, como queriam dar a ler suas trajetórias, lembranças e impressões. Em determinados casos, a redação dos testamentos foi aplicada de modo a conferir destaque aos bens deixados para escravos e ex-cativos, enjeitados e crias. Ao mesmo tempo, visava ressaltar sentimentos de benevolência, compaixão e misericórdia que as proprietárias afirmavam possuir. Registrar em testamento a generosidade para com aqueles que lhes serviram poderia funcionar, inclusive, como parte de um conjunto de estratégias da camada proprietária com vistas a manter a população cativa sob controle. De igual forma, fazia parte do ritual mais amplo de preparação para morte, sendo o reconhecimento e a gratidão ingredientes indispensáveis.

Nessa dimensão, ressaltamos as contribuições de Brian Street $^{21}$ - mesmo se reportando às práticas de letramento -, pois nos ajudam a pensar relações de poder e ideologia que perpassam as práticas envolvidas na escrita. No entendimento de Street, tais relações forjam as identidades e encontram-se vinculadas às expectativas e papéis sociais de cada sujeito ou de grupos. Lembramos que, enquanto partícipes delas, assumimos ou repelimos seus conteúdos e sentidos. Portanto, no referido contexto, deixar por escrito as virtudes de reconhecimento e gratidão era, sem dúvida, bem mais importante e marcante do que simplesmente dizê-las. Esse registro traduzia expectativas e valores emanados do lugar social ocupado pela testadora.

${ }^{21}$ STREET, Brian V. Literacy in theory and practice. Cambridge: Cambridge University Press, 1984, Cambridge studies in oral and literate culture, 9. 
No conjunto de mulheres proprietárias de escravos, alusões às alforrias das crias, à venda dessas, seu emprego para pagamentos de dívidas, dotes e legítimas, bem como outras referências são recorrentes. Os casos aqui selecionados nos serviram para analisar a utilização circunstanciada da escrita. Por isso, julgamos ser necessário tecer reflexões específicas a respeito.

\section{Algumas inferências}

Primeiramente, consideramos que a presença de crias nas vidas e nas casas de nossas testadoras determinou, no momento da elaboração de seus testamentos, a utilização a ser feita da escrita, de forma a descreverem a realidade, esmiuçando aspectos dessa convivência. Há, como demonstrado, diferenciações do papel e do lugar atribuído e ocupado por esse ator social em relação aos outros escravos ou ex-escravos, detalhes que os textos deixam à mostra.

Em segundo lugar, entendemos que as rememorações a respeito das crias, com as quais as testadoras conviveram, e a declaração dos sentimentos alegados evidenciam aspectos dessa sociedade ainda pouco abordados pela historiografia. Muito se disse sobre expostos, crianças abandonadas e órfãs na sociedade mineradora. Parece-nos importante, no entanto, que um olhar mais cuidadoso e curioso seja lançado para o estudo dos fenômenos relacionados ao ator social denominado cria.

Com efeito, destaca a historiografia que as crias serviram à reposição da mão de obra para os proprietários. Mas certo é, também, que seu papel enquanto agente social não pode ser subestimado. Importa saber, no entanto, como viveram e de que forma se relacionaram com seus senhores e senhoras no interior do espaço doméstico. Se se prestavam tão somente, por parte dos proprietários, a substituírem a compra de escravos adultos, como se explica a existência de número expressivo de alforrias de crias, principalmente nos testamentos de mulheres?

Por fim, as características levantadas nos textos nos quais há menção às crias denunciam a utilização da escrita aliada a aspectos peculiares da sociedade abordada. Nas diferenças identificadas e expostas nas redações, torna-se patente a função da escrita enquanto meio empregado para se definir o papel e o lugar de pessoas, que, mesmo sem serem consanguíneas, conviveram com as testadoras em suas casas e, presumivelmente, despertaram nelas alguns sentimentos. 
Durante a realização desta pesquisa, pudemos constatar, assim, a relevância de tomarmos o documento em sua singularidade, apesar de pertencer a uma série. Esforçamo-nos no objetivo de reavivar a particularidade de cada trecho redigido, das palavras e expressões selecionadas por quem as ditava. Intencionamos, com essa atitude, resgatar escritas originadas das falas de sujeitos comuns, numa abordagem que, se não completamente esquecida pela historiografia, parecia repousar à sombra da tendência em se analisar os papéis desempenhados pelas elites, autoridades, funcionários régios, ou seja, por protagonistas letrados pertencentes ou ligados diretamente às redes de poder.

Artigo recebido para publicação em 23/10/2014

Artigo aprovado para publicação em 25/11/2014 